\title{
Enteric Diarrheal Disease in Sheep Specially Campylobacter Infection
}

Ola A. A. Azmy

Bacteriology Department, Giza Lab., Animal Health Research

Institute, Cairo, Egypt.

\begin{abstract}
A TOTAL of 75 faecal samples were collected from 30 apparently normal and 45 diarrheic sheep. The bacteriological examination revealed isolation of $C$. jejuni and C. coli from $9(12 \%)$ and $3(4 \%)$ of examined sheep respectively. The prevalence of $C$. jejuni and $C$. coli were higher in the diarrheic sheep (15.6\%) and (4.4\%) than the apparently healthy $(6.66 \%)$ and $(3.33 \%)$ respectively. Campylobacter isolates were identified biochemically and serologically and using pathogenicity test two antigens cytotoxin and whole cell antigens associated with campylobacter. Campylobacter whole cell and cytotoxins were identified for their immunogenic activity by neutralization test and ELISA. Campylobacter isolates were also tested for susceptibility against 9 antibiotics.
\end{abstract}

Keywords: Campylobacter, Enteric diarrhea, Cytotoxin, Neutralization, ELISA, Antibiotic sensitivity.

Diarrhea is the most common symptom of illness in young sheep and calves. Scours can be caused by many organisms and more than one causative agent can be present in one animal. Although Salmonella, E.coli, and viruses such as rota virus are the most common cause of scours in young animals but protozoa such as cryptosporidia and coccidia and other bacteria such as campylobacter can also cause diarrhea (Radostitis et al., 2000).

Campylobacter is a Gram-negative slender, curved, and motile rod. It is a microaerophilic organism, which has a reduced level of oxygen. It is fragile and sensitive to several environmental stresses as $21 \%$ oxygen, drying, heating, disinfectants, and acidic conditions).Because of its microaerophilic characters, the organism requires 3 to $5 \%$ oxygen and 2 to $10 \%$ carbon dioxide for optimal growth conditions (Betty et al.,1998) and (Tongkorn, 2010). Campylobacter species are recognized as one of the major cause of diarrhea in domestic animals and human throughout the world (Butzler and Oosterom, 1991, Siemer et al., 2005). Moreover, epidemiological data have provided strong evidence that animals and food products of animal origin are the main sources for human infection (Shakespeare, 2002 and Hartmut et al., 2003). 
Several hypotheses have been proposed, based on clinical observations including suggestions that the organism is invasive, can produce cytotoxins and enterotoxins (Prasad et al., 1996 and Lee et al., 2000). Invasiveness is compatible with the occurrence of bloody diarrhea, often associated with endoscopic evidence of colitis or bacteraemia (Fernandez \& Trabulsi, 1995 and Coote et al., 2007). One of the mechanism by which Campylobacter species show its pathogenicity might be the production of toxins. Some of these toxins have a similarly to those of Vibrio cholera (Goossens et al., 1990 and Schulze et al., 1998). Both $C$. jejuni and $C$. coli produce a heat labile enterotoxin (McCardell et al., 1986). However $70 \%$ of $C$. jejuni and $C$. coli strains produce a cytotoxin. (Johnson and Lior, 1988 and Lee et al., 2000).

Some Campylobacter strains produce cytotoxic response in tissue culture system as Vero cell lines and the pathogenic significance of these cytotoxins has not been well evaluated (Muna, 2009). Increasing antimicrobial resistance in campylobacter is a recognized problem, (Sáenz et al., 2000 and Jensen and Aarestrup, 2001). The increasing uses of antibiotics in treatment of animal diseases especially enteric diseases may create more resistant strains of campylobacter in human and animal.

The aim of this work was:

- To study the prevalence of $C$. jejuni and $C$. coli in the feaces of lambs with and without diarrhea.

- To characterize the whole cell and cytotoxin antigen of campylobacter isolated from clinical cases.

- Study the susceptibility of Campylobacter isolated from lambs to 9 antibiotics.

\section{Material and Methods}

\section{Samples}

A total of 75 faecal swab samples were collected from sheep. Out of these samples, 45 were obtained from lambs (1-3 months age) suffering from severe diarrhea characterized by dark brown faeces with mucous and blood while the remaining 30 samples were taken from apparently healthy lambs during the period from August 2011 up to January 2012. All samples were collected and transported to the laboratory in the transport broth with supplement to preserve the organism from drying during transportation (OIE 2008).

\section{Isolation and identification of Campylobacter species}

Samples in transport broth with supplement were cultured directly onto modified Campylobacter blood free selective medium with antibiotics supplement (cefoperazon charcoal deooxycholate agar) (C.C.D.A) .The inoculated plates were incubated in an atmosphere of 5\% Oxygen, $10 \% \mathrm{CO}_{2}$ tension at $42^{\circ} \mathrm{C}$ for 48 hours using anaerobic gas generator kits (Gaspack kits). Suspected colony appeared flat, moist and translucent dew like when young.

Egypt. J. Vet. Sci. Vol. 44 (2013) 
Suspected colonies were picked up and purified onto thioglycolate media for further identification. Growing colonies were stained with Gram stain to demonstrate the characteristic morphology of the colonies (Cruckshank et al., 1975). Motility test was performed to demonstrate the cork screw like motion characteristic for campylobacter species. The isolates were identified biochemically and biotyped according to (Koneman et al., 1995) and (Quinn et al.,2002).

\section{Antibiotic sensitivity test}

The technique was carried out using the disc diffusion method according to Bopp et al. (1985). Bacterial isolates were tested for resistance using gradient

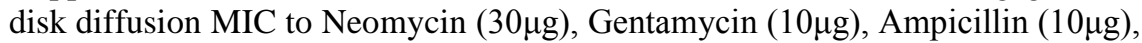

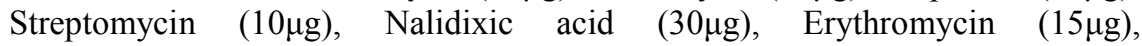
Chloramphenicol $(30 \mu \mathrm{g})$, Sulfamethoxazole $(25 \mu \mathrm{g})$ and Tetracycline $(30 \mu \mathrm{g})$ (Oxoid). Three colonies of Campylobacter organisms were inoculated into tubes containing $5 \mathrm{ml}$ Muller Hilton broth (Oxoid), then incubated for eight hours under reduced $\mathrm{O}_{2}$ tension at $37^{\circ} \mathrm{C}$. The turbidity was adjusted to match that of standard McFarland 0.5 barium sulphate tube $(0.5 \mathrm{ml}$ of $1.175 \%$ barium chloride hydrate at $99 \mathrm{ml}$ of $1 \%$ sulfuric acid) by adding sterile saline solution. The suspension was then inoculated evenly on 150-mm Muller Hilton agar plates supplemented with 5\% defibinated sheep blood. Different antibiotic discs were placed on the surface of agar plates. The plates were incubated for $72 \mathrm{~h}$ at $37^{\circ} \mathrm{C}$ under the microaerophilic conditions, and the inhibitory zone diameters were measured.

\section{Antigen preparation}

Whole cell antigen was prepared from fresh campylobacter strain grown on selective medium in a microaerophilic conditions at $42^{\circ} \mathrm{C}$ for $48 \mathrm{~h}$ then the organisms were harvested in sterile saline containing $0.5 \%$ formalin, incubate at $37^{\circ} \mathrm{C}$ overnight, washed once with BPS $(7.4 \mathrm{pH})$, suspended to concentration of $109 \mathrm{CFU}$ in PBS then stored at $4^{\circ} \mathrm{C}$ in saline containing $0.5 \%$ formalin. For titration the turbidity of the antigen preparation was standardized to correspond to the McFarland tube No.1 (Kosunen et al.,1981).

Cytotoxin was prepared from Campylobacter strains which were grown at $42^{\circ} \mathrm{C}$ for $24 \mathrm{~h}$ in selective medium supplemented with $1.0 \%$ Isovitalex under agitated condition in atmosphere of $10 \% \mathrm{CO}_{2}$ tension. For broth filtrates only treated with $2 \mathrm{mg}$ of polymyxinsulphate per $\mathrm{ml}$ at final 10 minutes. Cell free broth filtrates were obtained by centrifugation at $13000 \mathrm{Xg}$ for 10 minutes, and then the supernatants were sterilized by passages through $0.22 \mu \mathrm{m}$ pore size membrane filter. The sterile filtrate was concentrated and precipitated with $70 \%$ zinc sulphate solution, then suspended in 10 mMTris hydrochloride buffer according to Jennifer et al. (1991).

\section{Rabbit Immunization}

Three groups each of 5 rabbits were used, Two groups were inoculated with two different prepared antigens (whole cell antigen and cytotoxin antigen) 
cytotoxin was inoculated in the first group by injecting each animal with $(1 \mathrm{ml})$ via subcutaneous route (Derek et al.,1986) and injecting 109 CFU of whole cell antigen in the second group S/C while the third group were injected with physiological saline and kept as control serum (Yung et al., 1987).

\section{Neutralization assays}

$10 \mu \mathrm{l}$ sample of partially purified toxin $(100 \mu)$ was mixed with $10 \mu \mathrm{l}$ of serially diluted antisera obtained from naturally infected sheep, after $1 \mathrm{~h}$ incubation at $37^{\circ} \mathrm{C}\left(10^{6}\right)$ in $1 \mathrm{ml}$ of growth medium that was added, the cell showed morphological changes induced by cytotoxin (Yung et al., 1987).

\section{ELISA Assay}

Campylobacter antigens (whole cell and cytotoxin antigens) were used as coating antigens in detecting antibody levels against these antigens in naturally infected sheep and experimentally infected rabbits. Horseradish peroxidase (HRP) conjugated rabbit antisheep IgG was diluted in PBS in case of ovine serum samples while Labeled sheep anti-rabbit IgG was diluted in PBS in case of rabbit serum samples according to Derek et al. (1989).

\section{Results}

Table 1 illustrated that isolates of $C$. jejuni recovered from $7(15.6 \%)$ of the 45 diarrheic sheep which was higher than from $2(6.66 \%)$ of the apparently healthy sheep. Total number of positive samples of $C$. jejuni was $9(12 \%)$ of 75 rectal swab samples from sheep while $C$.coli was recovered from $2(4.4 \%)$ of the 45 diarrheic sheep which was higher than the apparently healthy sheep $(3.33 \%)$. Totally C.coli was isolated from $3(4 \%)$ of examined sheep samples.

TABLE 1. Incidence of Campylobacter species isolated from apparently healthy and

\begin{tabular}{|l|c|c|c|c|c|c|}
\hline \multirow{2}{*}{$\begin{array}{c}\text { Isolated } \\
\text { species } \\
\text { and } \\
\text { subspecies }\end{array}$} & \begin{tabular}{c} 
Apparently healthy \\
\cline { 2 - 7 } \\
isolates/number \\
of cases \\
examined
\end{tabular} & \multicolumn{2}{|c|}{ Diseased } & \multicolumn{2}{c|}{ Total } \\
\hline C. jejuni & $2 / 30$ & 6.66 & $\begin{array}{c}\text { Number of } \\
\text { isolates/number } \\
\text { of cases } \\
\text { examined }\end{array}$ & $\%$ & $\begin{array}{c}\text { Number of } \\
\text { isolates/ } \\
\text { number of } \\
\text { cases } \\
\text { examined }\end{array}$ & $\%$ \\
\hline C. coli & $1 / 30$ & 3.33 & $2 / 45$ & 4.4 & $3 / 75$ & 4 \\
\hline Total & $3 / 30$ & 10 & $9 / 45$ & 20 & $12 / 75$ & 16 \\
\hline
\end{tabular}

In-vetro Antimicrobial sensitivity

As shown in Table 2, C. jejuni isolated from sheep were sensitive to chloramphenicol $(90 \%)$ followed by gentamycin and neomycin. All C. jejuni isolated from sheep were resistant to penicillin, ampicillin, erythromycin and tetracycline.

Egypt. J. Vet. Sci. Vol. 44 (2013) 
ENTERIC DIARRHEAL DISEASE IN SHEEP SPECIALLY ...

TABLE 2. Antimicrobial sensitivity of Campylobacter jejuni isolated from sheep $(\mathbf{n}=10)$.

\begin{tabular}{|c|c|c|c|c|c|c|}
\hline \multirow{3}{*}{ Antibiotic } & \multicolumn{6}{|c|}{ C. jejuni } \\
\hline & \multicolumn{2}{|c|}{ Sensitive } & \multicolumn{2}{|c|}{ Moderate } & \multicolumn{2}{|c|}{ Resistant } \\
\hline & No & $\%$ & No & $\%$ & No & $\%$ \\
\hline Neomycin & 5 & 50 & 5 & 50 & 0 & 0 \\
\hline Gentamycin & 7 & 70 & 3 & 30 & 0 & 0 \\
\hline Ampicillin & 0 & 0 & 1 & 10 & 9 & 90 \\
\hline Erythromycin & 0 & 0 & 2 & 20 & 8 & 80 \\
\hline Chloramphenicol & 9 & 90 & 1 & 10 & 0 & 0 \\
\hline Nalidexic Acid & 0 & 0 & 4 & 40 & 6 & 60 \\
\hline Sulphamethoxazole & 0 & 0 & 2 & 20 & 8 & 80 \\
\hline Tetracycline & 0 & 0 & 2 & 20 & 8 & 80 \\
\hline Pencillin & 0 & 0 & 0 & 0 & 10 & 100 \\
\hline
\end{tabular}

$\mathrm{n}=$ number of examined isolates.

As shown in Table $3 \mathrm{C}$. coli isolated were sensitive to chloramphenicol $(70 \%)$ and gentamycin $(60 \%)$ while resistant to penicillin, ampicillin, tetracycline, erythromycin and nalidexic acid. The percentages of resistant strains of $C$. coli were higher than $C$. jejuni strains.

TABLE 3. Antimicrobial sensitivity of Campylobacter coli isolated from sheep $(\mathbf{n}=\mathbf{1 0})$.

\begin{tabular}{|l|c|c|c|c|c|c|}
\hline \multirow{2}{*}{\multicolumn{1}{c|}{ Antibiotic }} & \multicolumn{9}{c|}{ C. coli } \\
\cline { 2 - 7 } & \multicolumn{2}{|c|}{ Senstive } & \multicolumn{2}{c|}{ Moderate } & \multicolumn{2}{c|}{ Resistant } \\
\cline { 2 - 7 } & No & \% & No & \% & No & \% \\
\hline Neomycin & 5 & 50 & 3 & 30 & 2 & 20 \\
Gentamycin & 6 & 60 & 4 & 40 & 0 & 0 \\
Ampicillin & 0 & 0 & 1 & 10 & 9 & 90 \\
Erythromycin & 0 & 0 & 1 & 10 & 9 & 90 \\
Chloramphenicol & 7 & 70 & 3 & 30 & 0 & 0 \\
Nalidexic Acid & 0 & 0 & 1 & 10 & 9 & 90 \\
Sulphamethoxazole & 0 & 0 & 2 & 20 & 8 & 80 \\
Tetracycline & 0 & 0 & 1 & 10 & 9 & 90 \\
Pencillin & 0 & 0 & 0 & 0 & 10 & 100 \\
\hline
\end{tabular}

$\mathrm{n}=$ number of examined isolates.

Table 4 illustrated that high anticytotoxic antibody levels in serum of rabbits were significantly greater than antibody titer to whole cell antigen from $1^{\text {st }} 2^{\text {nd }}$, $3^{\text {rd }}$ and $4^{\text {th }}$ week post immunization. 
TABLE 4. Antibody response of immunized rabbits to cytotoxin and whole cell antigen using ELISA.

\begin{tabular}{|l|c|c|}
\hline Week post immunization/ Type of antigen & Cytotoxin & Whole cell \\
\hline First week & $0.514 \pm 0.0193$ & $0.416 \pm 0.0166$ \\
Second week & $0.663 \pm 0.0264$ & $0.5532 \pm 0.0183$ \\
Third week & $0.7514 \pm 0.0408$ & $0.5814 \pm 0.0221$ \\
Fourth week & $0.6928 \pm 0.0325$ & $0.5492 \pm 0.0257$ \\
\hline
\end{tabular}

Table 5 demonstrated that neutralization antibodies against cytotoxin in naturally infected sheep were significantly higher than whole cell antibodies.

TABLE 5. Neutralization of cytotoxin and whole cell antigens of campylobacter from sheep (sera from naturally infected sheep).

\begin{tabular}{|l|c|c|c|c|c|c|c|}
\hline Type of atigens/titer & $1 / 32$ & $1 / 64$ & $1 / 128$ & $1 / 256$ & $1 / 512$ & $1 / 1024$ & $1 / 2048$ \\
\hline Cytotoxin & + & + & + & + & - & - & - \\
Whole cell antigen & + & + & - & - & - & - & - \\
\hline
\end{tabular}

\section{Discussion}

Campylobacter species have been recognized as a cause of diarrhea in cattle and sheep (Radoststits et al., 2000). Campylobacter enteritis constitutes a zoonotic disease of major concern in public health and indeed has been shown to be a greater problem than Salmonellosis in several countries (Bacon et al., 1999). In the present study, it was of interest to note that out of 75 sheep showing diarrhea and apparently healthy, the occurrence of campylobacter reach 12 cases (16\%).These results agreed with findings of Yazicioghu (2000) who recorded $17.2 \%$ prevalence rate of campylobacter. While lower than $49 \%$ and $25 \%$ recorded by Garcia et al. (2010) and Rotariu et al. (2009) from sheep feces.

Data presented in Table 1 revealed that $C$. jejuni was isolated from examined sheep samples at a percentage of $(12 \%)$ while C.coli was isolated at a percentage of $(4 \%)$, so the prevalence of $C$. jejuni was higher than C.coli, these results support the observation of Busato et al. (1999) and Governor and Governor (2002) who reported that $C$. jejuni was most predominant isolates from diarrhoeic sheep followed by $C$. coli. As shown in Table 1 the prevalence of $C$. jejuni and C.coli was significantly higher in sheep suffering from diarrhea, this provided evidence of significant association between diarrhea and infection with $C$. jejuni and C. coli, this supported by the observation of Dodson and Lejeune (2005) who isolated $C$. jejuni from enteric diseased calves.

Furthermore in experimental study, Kerr (2004) found that oral inoculation of campylobacter was able to produce mild to moderate enteritis. In vitro antibiotic sensitivity test was done against strains of campylobacter using 9 antibiotics (Tables 2,3) illustrated that $C$. jejuni and $C$. coli were sensitive to

Egypt. J. Vet. Sci. Vol. 44 (2013) 
chloramphenicol, this support the data reported by (Oporto et al., 2009) who treated cases of campylobacter infection successfully with chloramphenicol. In addition, high percentage of isolates of $C$. jejuni and $C$. coli were resistant to Ampicillin, tetracyclin, Erythromycin, Nalidexic acid and sulfamethoxazole but drug resistance was more frequent in $C$. coli than $C$. jejuni. These findings are agree with that recorded by Chuma et al. ( 2001) and Bae et al. (2005), they demonstrated that there was a very low prevalence of resistance among $C$. coli isolates, while (Anthony and Ellen, 2000) and (Shakespeare, 2002) explained that using of antibiotics in animal treatment may promote the emergence of multi-antibiotic resistant mutant of campylobacter species.

The virulence of Campylobacter species based mainly on the adherent, invasiveness and cytotoxin production which has been detected in several different strains of $C$. jejuni and has been confirmed to be toxic. These toxins play an important role in the pathogenesis of Campylobacter jejuni infection (Klipstin et al., 1985). Cytotoxin produced by campylobacter was considered to be the primary virulence factor in the pathogenesis (Wassenaar, 1997) and (Schulze et al., 1998). Cytotoxin facilitates invasion and spread of the organism following entry via the alimentary tract (Wong et al., 1983) and (Pickett, 2000) Serum antibody titer have been associated with increase resistance to campylobacter in sheep while whole cell antigen stimulate somatic cell immune response which doesn't consistently provide high protective antibody titer. (Gurturk et al., 2007).

To evaluate the humoral immune response of rabbits immunized with cytotoxin and whole cell antigen using ELISA, data presented in table (4) illustrated the significant increase in antibody titre during different intervals post immunization in rabbits immunized by cytotoxin than rabbits immunized by whole cell antigen according to (Bacon et al.,1999) and (Blaser and Duncan, 1984). These results indicated that the protective immunity could be manifested by cytotoxin antigen than the whole cell antigen, this could be attributed to higher immunogenic feature of cytotoxin as concluded by (Coote et al., 2007).

The results of this study suggest that exposure to cytotoxin antigen may be necessary to produce an anticytotoxin immune response and that response is better predictor of resistance to campylobacter than the immune response to whole cell antigen. ELISA cytotoxin antibody response was significantly higher than those for the whole cell antigen recorded by (Blaser and Perez, 1993) and (leunk et al., 1988) found that cytotoxin activation of peripheral blood monocytes, macrophages and when incubated with neutrophil resulted in neutrophil activation. 


\section{References}

Anthony, E.B. and Ellen, E.S. (2000) Epidemiology of resistance to antibiotics: Links between animals and humans. International Journal of Antimicrobial Agents, 14 (4), $327-335$.

Bacon, D.J., Johnson, W.M. and Rodgers, F.G. (1999) Identification and characterization of a cytotoxic porin-lipopolysaccharide complex from campylobacter jejuni. J. Med. Microbiol., 48, 139-148.

Bae, W, Kaya, K.N., Hancock, D.D., Call, D.R., Park, Y.H. and Besser, T.E. (2005) Prevalence and antimicrobial resistance of thermophilic Campylobacter spp. from cattle farms in Washington State. Appl. Environ. Microbiol., 71 (1), 169-174.

Betty, A., Dniel, F. and Alice, S.W. (1998) "Baileey's and Scott's Diagnostic Microbiology", $10^{\text {th }}$ ed., Mosby.

Blaser, M.J. and Duncan, D.J. (1984) Human serum antibody response to campylobacter jejuni infection as measured in an Enzyme linked immunosorbant assay. Infection and Immunity, 44 (2), 292-298.

Blaser, M.J. and Perez-Perez, G.I. (1993) Humoral immune response to lipopolysaccharide antigens of campylobacter jejuni. American Society for Microboil. Washington DC.

Bopp, F.L., Bikness, K.A., Washsmuth, I.K. and Barrett, T.J. (1985) In vetro antimicrobial susceptibility, plasmid analysis and serology of epidemic Campylobacter jejuni. J. Clin. Microbiol., 21 (1), 4-7.

Busato, A., Hofer, D., Lentze, T., Gaillard, C. and Burnens, A. (1999) Prevalence and infection risk of zoonotic enteropathogenic bacteria in Swis cow-calf farms. Vet. Microbiol., 69, 251-263.

Butzler, P.J. and Oosterom, J. (1991) Campylobacter:pathogenicity and significance in foods. International J. Food Microbiol., 12, 1-8.

Chuma, T., Ikeda, T., Maeda, H., Niwa, and Okamoto, K. (2001) Antimicrobial susceptibilities of Campylobacter strains isolated from broilers in the southern part of Japan from 1995 to 1999. J. Vet. Med. Sci., 63, 1027-1029.

Coote, J.G., Stewart-Tull, D.E.S., Owen, R.J., Bolton, F.J., Siemer, B.L., Canadlish, D., Thompson, D.H., Wardlaw, A.C.On, S.L.W., Canadlish, A., Billcliffe, B., Jordan, P.J., Kristiansen, K. and Borman, P. (2007) Comparison of virulence associated in vitro properties of typed strains of campylobacter jejuni from different sources. J. Med. Microbiol., 56, 722-732.

Cruckshank, R.D., Duguid, J.P., Mermion, B.R. and Swain, R.H.A. (1975) "Text Book of Practical Microbiology", $12^{\text {th }}$ ed., living stone (London) New York.

Derek, A.M., Lessley, B.A., Anthony W. C, Antone S.M., and Gentry, M.J. (1986) Chromatographic separation and characterization of Pasteurellahaemolyticacytotoxin. American Journal of Veterinary Research, 47 (10), 2233-2241.

Egypt. J. Vet. Sci. Vol. 44 (2013) 
Derek, A., Mosier, K.R., Simons, A. W., Confer, R.J. P. and Kenneth D. C. (1989) Serum IgG and IgM antibody response in cattle to antigens of Pasteurella haemolytica. Veterinary Immunology and Immunopathology, 22 (1), 53-65.

Dodson, K. and LeJeune, J. (2005) Escherichia coli O157:H7, Campylobacter jejuni, and Salmonella prevalence in cull dairy cows marketed in northeastern Ohio. J. Food Prot., 86 (5), 927-31.

Fernanadez, H. andTrabulsi, L.R. (1995) lnvasive and enterotoxin properties in Campylobacter coli strains isolated from humans and animals. Biol. Res., 28 (3), 205-210.

Garcia, A., Steele, W.B., and Taylor, D.J. (2010) Prevalence and Carcass Contamination with Campylobacter in Sheep Sent for Slaughter in Scotland. Journal of Food Safety, 30 (1), 237-250.

Goossens, H., Pot, B., Vlacs, L. and Boeck, D.C. (1990) Is Campylobacter recognized cause of human diarrhea. Lancet, 335, 584-586.

Governor C. C. and Governor L. K. G. (2002) "Campylobacter infections." Centers for Disease Control (CDC), Dec 2001. 24 Oct, State of New Jersy, Department of Agriculture.

Gurturk, K., Ekin, I.H. and Arslan, A. (2007) Western blot analysis of the $\operatorname{IgG}$ antibody resposes to acid glycin extracted antigens from campylobacter jejuni in naturally infected sheep. Acta Vet. Brno, 76, 245-251.

Hartmut, K., Albert, W., Max, A., Burkhard, E., Henry, D., Hans G. S., Werner, S., Alexander, V. and Horst, Z. (2003) Zoonoses, infectious diseases transmissible from animals to humans. $3^{\text {rd }}$ ed. American Society for Microbiology, Washington D.C.

Jennifer, A.C., Patrica, E.S. and Reggie, Y.C. (1991) Efficacy of Recombinant leukotoxin in protection against pneumonic challenge with live pasteurella haemolytica A1. Infection and Immunity 59 (2), 587-591.

Jensen, L.B., and Aarestrup, F.M. (2001) Macrolide resistance in Campylobacter coli of animal origin in Denmark. Antimicrob. Agents Chemother., 45, 371-372.

Johnson, W. and Lior, H. (1988) A new heat labile cytolethal distending toxin (CLDT) by campylobacter species. Microbial. Pathogenesis, 4, 115-126.

Kerr, S.R. (2004) An overview of calf scour. Fact sheet No. 104, Central agriculture Washington animal team, Washington state university.

Klipstein, F.A., Engert, R.F., Short S.M. and Schenk, E.A. (1985) Pathogenic properties of Campylobacter jejuni assay and correlation with clinical manifestations. Inflmm., 50 (1), 43-49.

Koneman, E.W., Alle, D., Linda, W.M., Schrcckenherger, I.C. and Winn, W.C. Lippincoi (1995) "Introduction to Diagnostic Microbiology" $5^{\text {th }}$ ed., Company, Philadephia, (USA). 
Kosunen, T.U., Pitkanen, T.,Pettersson, T. and Ponka, A. (1981) Clinical and serological Studies in patients with Campylobacter fetus Sp. Jejuni Infection: II Serological Findings. Infection, 9 (6), 279-282.

Lee, A., Smith, S.C. and Coloe, P.J. (2000) Detection of a 4noval Campylohactercytotoxin. J. Appl. Microbiol., 8 (4) 719-725.

Leunk, R.D., Johnson, P.T., David, B.C., Kraft, W.G. and Morgan, D.R. (1988) Cytotoxic activity in broth culture filtrates of campylobacter. J. Med. Microbiol., 26, 93-99.

McCardell, B.A., Madden, J.M. and Stanfield, J.T. (1986) Effect of iron concentration on toxin production in C.jejuni and C.coli, Can. J. Microbiol., 32, 395-401.

Muna, S. Al-Delaimi (2009) Cytopathic effect of cytotoxin produced by Campylobacter jejuni on tissue culture cells. J. Duhok Univ., 12 (1), 275-281.

OIE Terrestria Manual (2008) Campylobacter Jejuni and Campylobacter Coli. Chapter 2.9.3. pp.1185-1191.

Oporto, B., Juste, R.A. and Hurtado, A. (2009) Phenotypic and Genotypic Antimicrobial Resistance Profiles of Campylobacter jejuni Isolated from Cattle, Sheep, and Free-Range Poultry Faeces. Int. J. Microbiol., pp. 456-573. Mar 8.

Pickett, C.L. (2000) Campylobacter Toxins and their Role in Pathogenesis, in Campylobacter, $2^{\text {nd }}$ ed. pp. 179-190., I. Nachamkin \& M.J. Blaser (Ed.), Washington DC, American Society for Microbiol.

Prasad, K.N., Dholc, T.N. and Ayyagari, A. (1996) Adherence, invasion and cytotoxin assay of Campylobacter jejuni in Hela and Hop-2 cells. J. Diarrhocal Dis. Rcs., 14 (4), 255-259.

Quinn, P.J., Markey, P. K., Carter, M.E., Donnelly, W.J. and Leonard, F.C. (2002) "Veterinary Microbiology and Microbial Diseases". Black Well Science Ltd.

Radostits, O.M., Gay, C.C., Blood, D.C. and Hinchliff, K.W. (2000) "Veterinary Medicine", A text book of the diseases of cattle, sheep, pigs, goats and horses. $9^{\text {th }}$ ed. W.B. Saunders Company Ltd., London.

Rotariu, O., Dallas, J.F., Ogden, I.D., MacRae, M., Sheppard, S.K., Maiden, M.C., Gormley, F.J., Forbes, K.J. and Strachan, N.J. (2009) Spatiotemporal homogenecity of Campylobacter subtypes from cattle and sheep across northeastern and southwestern Scotland.Appl Environ Microbiol., 75 (19), 6275-81.

Sáenz, Y., Zarazaga, M., Lantero, M., Jose Gastañares, F., Baquero, M. and Torres, C. (2000) Antibiotic resistance in Campylobacter strains isolated from animals, foods and humans in Spain in 1997-1998. Antimicrob. Agents Chemother., 44 (2), 267-271.

Schulze, F., Hanel, I. and Borrmann, E. (1998) Formation of cytotoxins by enteric Campylohacter in humans and animals. Zentralbl. Bakteriol., 288 (2), 225-236.

Egypt. J. Vet. Sci. Vol. 44 (2013) 
Shakespeare, M. (2002) Zoonoses pharmaceutical press. Clinical Infectious Diseases., 32 (8), 1201-1206.

Siemer, B.L., Nielsen, E.M., and On, S.L.W. (2005) Identification and molecular epidemiology of campylobacter coli isolates from human gastroenteritis, food and animal sources by amplified fragments length polymorphism analysis and pennerserotyping. Appl. Environ. Micobiol., 7, 1953-1958.

Tongkorn, M. (2010) Zoonotic Agents in sheep farms in Brandenburg, Germany. Doktoras der veterinarmedizin, Freien Universitat, Berlin.

Wassenaar, T.M. (1997) Toxin production by campylobacter species. Clin. Microbiol. Rev., 10 (3),466.

Wong, P.Y., Puthucheary, S.D. and Pang, T. (1983) Demonstration of cytotoxin from campylobacter jejuni. J.Clin.Path., 36, 1237-1240.

Yazicioghu, N. (2000) The relationship between Campylobacter colonization and serum antibody levels in sheep. Etiik. Veteriner. Mikrobiyoloji Dergisi., 1 (112), 31-45.

Yung-Fu Chang, RY Young, David Post and Douglas K.Struk. (1987) Identification and characterization of the pasteurella haemolyticaleukotoxin. Infection and Immunity, 55 (10), 2348-2354.

(Received 24/12/2013;

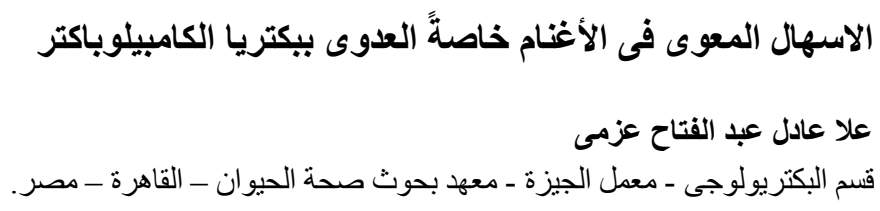

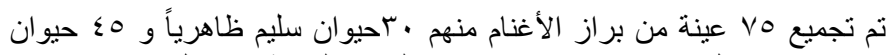

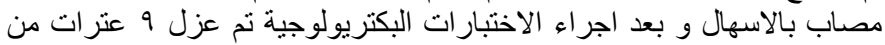

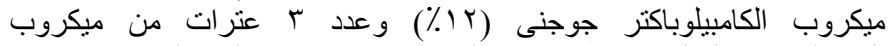

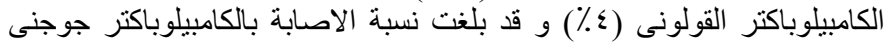

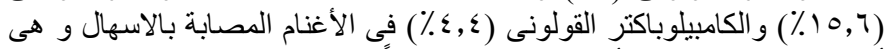

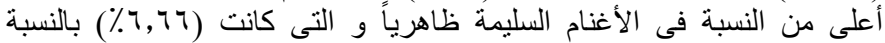

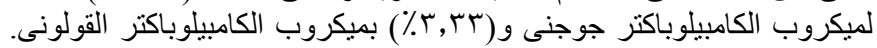

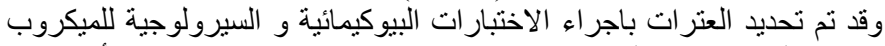

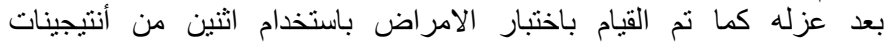

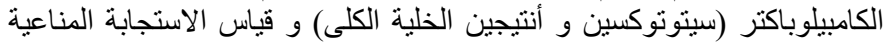

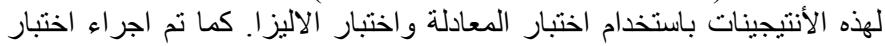

الحساسية للعتر ات المعزولة باستخدام 9 من المضادات الختار الحيوية.

Egypt. J. Vet. Sci. Vol. 44 (2013) 